\title{
Analysis of Fire Control Hotel in Palembang City
}

\author{
Jimmy Tiarlina ${ }^{1 *}$, Novrikasari ${ }^{1}$, and Rico Januar Sitorus $^{3}$ \\ ${ }^{1}$ Faculty of Environmental Health, Universitas Sriwijaya, South Sumatra, Indonesia
}

\begin{abstract}
The Regulation of the Minister of Public Works Number: 26 / PRT / M / 2008 about technical requirements of fire protection in buildings and environments has not been implemented optimally in hotels. The purpose of this research is to analyze the fire prevention system of hotel building in Palembang City. The research design was Cross Sectional, sampling technique used Stratified Random Sampling with 31 hotels as the sample. Data analysis used Chi Square test. The result of this research shows that from 31 hotels, $74.2 \%$ have good fire prevention system, $58.06 \%$ of fire officer access is eligible, $93.55 \%$ of water supply is eligible, $83.87 \%$ of the tools of rescue is eligible, $74.19 \%$ of active protection system is eligible, $74.19 \%$ of knowledge of fire manager is eligible. The result of statistical analysis showed that there is no correlation between access of fire fighter, water supply and active protection system with the fire prevention system at hotel. The related factors were the tools of rescue; passive protection system; the knowledge of fire safety manager. The conclusions of this research is the related factors that has relation with fire prevention facilities at hotels in Palembang City is the tools of rescue, passive protection system and knowledge of fire safety manager. The writer suggests to improve the fire prevention knowledge for all hotel staff, to inform visitors about the way route of escape, the improvement of routine maintenance and coaching from managerial and the existence of further research on fire prevention system.
\end{abstract}

\section{Introduction}

One consideration of the tourists in choosing their holiday destination is a guarantee of security from their destination.[1] Indonesia provides security assurance to the visitors of the hotel with the issuance of Regulation of the Minister of Tourism for Creative Economy Number 106 in 2011.

The estimation of hotels' fire from 2009-2013 is 3520 fires per year occurred in the United States, caused 9 deaths, 120 injuries and \$ 84 millions in asset losses. Most fire sources are from the kitchen, which are the two of every five fires $(41 \%)$, due to heating equipment $(9 \%)$, clothing dryer $(8 \%)$, smoking $(8 \%)$, carelessness $(9.2 \%), 3.3 \%)$, play with heat source $(0.3 \%)$ and $11.1 \%$ flame. These fires accounted for $8 \%$ mortality, $25 \%$ injuries and $8 \%$ asset damage.[2] Nasya et al conducted a study on hotels in the former administrative city of Jember, found that only $11.11 \%$ of hotels implemented fire management system[3]

Short circuits that can emit fire is able to trigger fires in hotels. Elements of deliberate activity such as sabotage, revenge can also be a trigger of fire. [4] 
Fire is an event that cause the loss of life and assets, disrupting and even crippling the production process and causing air pollution [5].

The regulation of the Minister of Public Works Number: 26/PRT/M/2008 on the technical requirements of fire protection systems in buildings and the environment states that buildings must be functional safely for the environment to have fire protection system from the planning, implementation, development stage to the utilization stage [6].

According to the Injunction of The Minister of Public Works No. 02/KPTS/1985, the hotel building is a Class A building with the main structural components that must be fireproof at least 3 (three) hours[7].

Rijanto said that the fire hazard in buildings generally will be related to the location and the age of buildings, building construction, building contents, management factors, human factors and fire protection systems [8].

The purpose of this study was to analyze the fire prevention system of hotels in Palembang City. In this research there are 6 hypothesis such as (1)There is a relation of fire officers and hotel fire prevention system in Palembang City, (2) There is a relation between the water supply system and the hotel fire prevention system in Palembang City, (3) There is a relation between the tools of rescue and fire prevention system of hotel in Palembang City, (4) There is a relation between active protection system and fire prevention system 2018 , (5) There is a relation of passive protection system and hotel fire prevention system in Palembang City, (6) There is a relationship between the level of knowledge and system of fire prevention of the existing hotels in Palembang City.

\section{Materials and Methods}

The research design that is used in this research is cross Sectional. The research target is hotel in Palembang City from 44 population of the hotel, the number of sample is 31 samples, obtained with this formula:

$$
n=\frac{N}{1+N(d)^{2}}
$$

Information:

$\mathrm{n}=$ number of sample

$\mathrm{N}=$ Total of population

$\mathrm{d}=$ the level of trust

The sampling technique used this stratified random sampling

Table 1. Distribution of sample

\begin{tabular}{|c|c|c|c|}
\hline Number & Star & $\begin{array}{c}\text { The Amount of } \\
\text { Hotels }\end{array}$ & Sample Technique \\
\hline 1. & 1 star & 7 & $\frac{7}{44} \times 31=5$ \\
\hline 2. & 2 star & 16 & $\frac{7}{44} \times 31=5$ \\
\hline 3. & 3 star & 10 & $\frac{7}{44} \times 31=5$ \\
\hline 4. & 4 star & 9 & $\frac{7}{44} \times 31=5$ \\
\hline 5. & 5 star & 2 & $\frac{7}{44} \times 31=5$ \\
\hline
\end{tabular}




\section{Results and Discussions}

Based on research at 31 hotels in Palembang City, the results that can be seen in the following in Table 2 .

Table 2. Distribution of hotels' fire prevention, access, water supply, tools of rescue, active protection system, passive protection system, and knowledge In Palembang City.

\begin{tabular}{|c|c|c|c|c|}
\hline \multirow{2}{*}{ Variable } & \multicolumn{2}{|c|}{ Not Eligible } & \multicolumn{2}{|c|}{ Eligible } \\
\hline & $\mathbf{n}$ & $\%$ & $\mathbf{n}$ & $\%$ \\
\hline $\begin{array}{c}\text { FIRE PREVENTION } \\
1 \text { Stars }\end{array}$ & 3 & 9.7 & 2 & 6.5 \\
\hline 2 Stars & 3 & 9.7 & 8 & 25.8 \\
\hline 3 Stars & 2 & 6.5 & 5 & 16.1 \\
\hline 4 Stars & 0 & 0.0 & 6 & 19.4 \\
\hline 5 Stars & 0 & 0.0 & 2 & 6.5 \\
\hline $\begin{array}{l}\text { ACCESS } \\
1 \text { Stars } \\
\end{array}$ & 2 & 6.5 & 3 & 9.7 \\
\hline 2 stars & 6 & 19.4 & 5 & 16.1 \\
\hline 3 stars & 3 & 9.7 & 4 & 12.9 \\
\hline 4 stars & 2 & 6.5 & 4 & 12.9 \\
\hline 5 stars & 0 & 0 & 2 & 6.5 \\
\hline $\begin{array}{c}\text { WATER SUPPLY } \\
1 \text { Stars } \\
\end{array}$ & 2 & 6.45 & 3 & 9.7 \\
\hline 2 stars & 0 & 0 & 11 & 35.5 \\
\hline 3 stars & 0 & 0 & 7 & 22.6 \\
\hline 4 stars & 0 & 0 & 6 & 19.4 \\
\hline 5 stars & 0 & 0 & 2 & 6.5 \\
\hline $\begin{array}{c}\text { TOOLS OF RESCUE } \\
\text { 1 Stars }\end{array}$ & 2 & 6.5 & 3 & 9.7 \\
\hline 2 stars & 2 & 6.5 & 9 & 29 \\
\hline 3 stars & 1 & 3.2 & 6 & 19.4 \\
\hline 4 stars & 1 & 3.2 & 5 & 16 \\
\hline 5 stars & 0 & 0 & 2 & 6.5 \\
\hline $\begin{array}{c}\text { ACTIVE PROTECTION } \\
1 \text { Stars } \\
\end{array}$ & 1 & 3.2 & 4 & 12.9 \\
\hline 2 stars & 3 & 9.7 & 8 & 25.8 \\
\hline 3 stars & 1 & 3.2 & 6 & 19.4 \\
\hline 4 stars & 0 & 0.0 & 6 & 19.4 \\
\hline 5 stars & 0 & 0.0 & 2 & 6.5 \\
\hline $\begin{array}{c}\text { PASSIVE PROTECTION } \\
1 \text { Stars }\end{array}$ & 4 & 12.9 & 1 & 3.2 \\
\hline 2 stars & 5 & 16.1 & 6 & 19.4 \\
\hline 3 stars & 3 & 9.7 & 4 & 12.9 \\
\hline 4 stars & 0 & 0.0 & 6 & 19.4 \\
\hline 5 stars & 0 & 0.0 & 2 & 6.5 \\
\hline $\begin{array}{c}\text { KNOWLEDGE } \\
1 \text { Stars } \\
\end{array}$ & 5 & 16.1 & 0 & 0.0 \\
\hline 2 stars & 1 & 3.2 & 10 & 32.3 \\
\hline 3 stars & 2 & 6.5 & 5 & 16.1 \\
\hline 4 stars & 0 & 0.0 & 6 & 19.4 \\
\hline 5 stars & 0 & 0.0 & 2 & 65 \\
\hline
\end{tabular}


Fire Prevention The Result of this research found that $74.2 \%$ of hotels in Palembang City has good fire prevention system. The best is done by 5 stars hotel $(6.5 \%)$ dan 4 stars hotel $(25.81 \%)$. The availability of good human resources is $58.06 \%$, good house keeping is $93.5 \%$, having emergency response procedure is $16.13 \%$, having good storage warehouse is $67.75 \%$.

Access Hotel access distribution in Palembang City is assessed from the research result of hotel building environment that fulfill the requirement $58.06 \%$ and $100 \%$ for fire officer access. Based on data in table 3, from 31 hotels that is researched, 18 hotels $(58.06 \%)$ in Palembang City have access that is eligible.

Water Supply The water supply system of 31 hotels are $93.55 \%$ which are eligible, hotel which is not eligible were found in 1 star Hotel.

Tools of Rescue The result of this study found that has $83.87 \%$, of the hotels has eligible exit way, the emergency stair that is eligible is $83.87 \%$, the eligible fire evacuation symbol is $70.97 \%$, the eligible fire assembly point is $80.65 \%$. Statistical data above shows that $90.32 \%$ of hotels in Palembang City have a eligible rescue facility.

Active Protection System The results of this study found that 31 hotels, alarm and detectory which is eligible is $83.87 \%$, pole hydrants which is eligible is $67.74 \%$, eligble hydrant wall is $100 \%$, eligible automatic sprinkler is $96.78 \%$, eligible fire extinguisher is 90.33\%.

Passive Protection System The results showed that 19 hotels $(61.3 \%)$ of the hotels had eligible passive protection system. It was found that 11 hotels $(38.7 \%)$ have passive protection systems that is not eligible. The hotel wall which is eligible is $100 \%$, the door is eligible at $70.96 \%$. Based on these results then calculated passive protection system presented in table 2.

Knowledge Respondents were fire managers, Table 2 shows that in Palembang City $74.2 \%$ of hotel fire managers have good knowledge level.

\subsection{Bivariate Analysis}

To see the relation between independent variable and dependent variable, chi-square test is done in this research, the result is presented in Table 3.

Tabel 3. The Relation among Access, Water Supply, Tools of Rescue, Active Protection, Passive Protection with Hotel Fire Prevention Palembang City.

\begin{tabular}{|c|c|c|c|c|c|c|}
\hline \multirow{2}{*}{\multicolumn{2}{|c|}{$\begin{array}{c}\text { Independent } \\
\text { Variable } \\
\end{array}$}} & \multicolumn{2}{|c|}{ Prevention } & \multirow{2}{*}{ Total } & \multirow{2}{*}{$\begin{array}{c}P- \\
\text { Value }\end{array}$} & \multirow{2}{*}{ OR } \\
\hline & & \multirow{2}{*}{$\begin{array}{c}\text { Not Good } \\
4(30.8 \%) \\
\end{array}$} & \multirow{2}{*}{\begin{tabular}{|r|} 
Good \\
$9(69.2 \%)$ \\
\end{tabular}} & & & \\
\hline Access & $\mathrm{NE}$ & & & $13(100 \%)$ & \multirow{2}{*}{0.698} & \multirow{2}{*}{$\begin{array}{l}1.556 \\
4.833(2.3708-7.854) \\
\end{array}$} \\
\hline & $\mathrm{E}$ & $422.2 \%)$ & $14(77.8)$ & $18(100 \%)$ & & \\
\hline \multirow{2}{*}{$\begin{array}{l}\text { Water } \\
\text { Supply }\end{array}$} & $\mathrm{NE}$ & $2(100 \%)$ & $0(0.00 \%)$ & $2(100 \%)$ & \multirow[b]{2}{*}{0.060} & \multirow{2}{*}{$\begin{array}{l}1.500(0.412-78.059) \\
5.300(0.821-48.342)\end{array}$} \\
\hline & $\mathrm{E}$ & $6(20.7 \%)$ & $23(79.3 \%)$ & $29(100 \%)$ & & \\
\hline \multirow{2}{*}{$\begin{array}{l}\text { Tools of } \\
\text { Rescue }\end{array}$} & $\mathrm{NE}$ & $4(66.7 \%)$ & $2(33.3 \%)$ & $6(100 \%)$ & \multirow[b]{2}{*}{0.026} & \multirow{2}{*}{$\begin{array}{l}0.333(1.150-0.742) \\
1,556(0,308-7,854)\end{array}$} \\
\hline & $\mathrm{E}$ & $4(16.0 \%)$ & $21(84.0 \%)$ & $25(100 \%)$ & & \\
\hline \multirow{2}{*}{$\begin{array}{l}\text { Active } \\
\text { Protection } \\
\text { system }\end{array}$} & $\mathrm{NE}$ & $3(60.0 \%)$ & $2(40.0 \%)$ & $5(100 \%)$ & \multirow[b]{2}{*}{0.093} & \multirow{2}{*}{$\begin{array}{l}4.833(2.370-9.856) \\
1.500(0.412-78.059)\end{array}$} \\
\hline & E & $5(19.2 \%)$ & $21(80.8 \%)$ & $26(100 \%)$ & & \\
\hline \multirow{2}{*}{$\begin{array}{l}\text { Passive } \\
\text { Protection } \\
\text { System }\end{array}$} & $\mathrm{NE}$ & $8(66.7 \%)$ & $4(33.3 \%)$ & $12(100 \%)$ & \multirow[b]{2}{*}{0.000} & \multirow[b]{2}{*}{$5.300(0.821-48.342)$} \\
\hline & $\mathrm{E}$ & $0(0.00 \%)$ & $19(100 \%)$ & $19(100 \%)$ & & \\
\hline
\end{tabular}


Access Variable, the results show that there is no significant difference between $p$ (o, $689)>\alpha(0.05)$, which indicates no relation between access and fire prevention.

Water Supply Variable, there is no significant difference with $p$ value $(0.060)>\alpha$ $(0.05)$ that indicates there is no correlation between water supply and fire prevention implementation.

Tools of rescue, there is significant differences with $p$ value $(0.026)<\alpha(0.05)$ that indicates there is a relation between the tools of rescue with fire prevention. PR score $(10.500)>1$ indicates that tools of rescue are at risk 10,500 times greater in poor fire prevention.

Active Protection System Variable, there is no significant difference between $p$ value $(0.093)>\alpha(0.05)$ that indicates that there is no correlation between active protection and fire prevention.

Passive Protection System Variable, there is significant difference between $p$ value $(0.000)<\alpha(0.05)$ that indicates there is a relation between passive protection and fire prevention. PR value $(0.333)<1$, which means passive protection system become a protection factor in fire prevention.

Table 4. The Relation between Knowledge and Fire Prevention

\begin{tabular}{|c|c|l|c|c|c|}
\hline \multirow{2}{*}{ Knowledge } & \multicolumn{2}{|c|}{ Fire Prevention } & \multirow{2}{*}{ Total } & \multirow{2}{*}{$\boldsymbol{P}$ score } & $\begin{array}{c}\text { PR } \\
\mathbf{9 5 \%}\end{array}$ \\
\cline { 2 - 3 } & Not Good & Good & & & $11,111(1,701-$ \\
Bad & $5(62,5 \%)$ & $(37,5 \%)$ & $8(100 \%)$ & \multirow{2}{*}{0,013} & $72,564)$ \\
\hline Good & $3(13,0 \%)$ & $(87,0 \%)$ & $23(100 \%)$ & $0,013)$ \\
\hline
\end{tabular}

Statistical data in the table above shows that there is significant difference between $p$ value $(0.013)<\alpha(0.05)$ that indicates there is correlation between fire manager knowledge with fire prevention. PR score (11.111) $>1$ indicates that subjects with poor knowledge are at risk 11.1 times bigger than the poor fire prevention.

Fire prevention systems are said as good Fire prevention systems if some facilities are eligible including access, water supply, tools of rescue, active protection systems, passive protection systems and fire manager knowledge about fire prevention.

There is no relation between these two variables can be seen from the statistical analysis where the value of $p(0.689)>\alpha(0.05)$. The results of this study are not in accordance with the provisions with fire security regulation of the building which one of them is Minister of Public Works Regulation Number 26 in 2008. Sucipto said that good officer access/road (hard and wide road structures) is needed for the mobilization of fire trucks which sometimes have to go in and out to take water and also for evacuation purposes[9]. Four and five star hotels are eligible either from the access side of the building environment which the race is eligible according with the terms of the law. Three-stars hotel or lower are located in a crowded area such as mall, shop house and market area. The distance between the hotel building and its equivalent does not comply with the existing regulations. The concept of low budget that carried by the hotel is a facility that provides minimalist facilities.

Increasing the risky place supervision every day, it is very effective to prevent fires caused by the various functions which is one of the keywords that can be done in terms of fire prevention of the hotel [10].

The result of statistical analysis shows that there is no any relation with $p$ value $(0.060)>\alpha(0.05)$ this is not in line with Minister of Public Works regulation Number 26 in 2008 which explains that the building environment must have a water source in the form of 
hydrant yard, fire well or water reservoir, eligible water supply is said that is able to supply water flow to the entire building environment. In the absence of a good distribution system, buildings shall be permitted to provide reservoirs, pressurized tanks or other suitable systems.

The results shows that there is a significant correlation between mortality statistics with fire prevention, $p$ value $(0.026)<\alpha(0.05)$, with $95 \%$ CI $1.412-78.059$. The values needed of this relation is 10.5 which means the tools of rescue is a factor that is makes fire prevention become worst in the hotel in Palembang City.

Interviews of hotel visitors showed that not all visitors noticed the evacuation route, some said they didn't get information, some visitors said if they were tired and did not pay attention to the evacuation route information.

The result shows that $29 \%$ of hotels in Palembang make evacuation route as a warehouse, this condition is contrary to the SNI 03-1746-2000 which said that the evacuation route should be maintained, free from all obstacles and obstacles must be used completely in the event of fire or in the event of another emergency[11].

The result of the research shows that there is no correlation between active protection and fire prevention. The result shows that there is significant difference between $p$ value $(0.093)>\alpha(0.05)$ This is not in line with Law Number 28 Year 2002 which explaine $d$ explaining the terms of the ability of building buildings in coping with fire one of them has a means of active protection system.

The result shows that $p(0.000)<\alpha(0.05)$ with $95 \%$ CI $0.150-0.742$ indicated that there was a relation between passive protection and fire prevention. PR value $(0.333)<1$, which means passive protection system is a protection factor in fire prevention implementation, this is in line with some regulations which is one of them is Minister of Public Works Regulation Number 26 in 2008.

This study found a relation between knowledge with fire prevention in buildings indicated by $p$ value $(0.013)<\alpha(0.05)$. It is in line with $\mathrm{Hu} \mathrm{Y}$ in his research which said that according to statistical data in China, from 2006 to 2015 there have been 294 fires in the hotel, $36.94 \%$ of them are caused by unsafe behavior of officers. Officers who work without regard to security is caused by the lacking of knowledge of officers so they can work safely, and the behavior of officers who are less aware to work safely.

\section{Conclusion}

According to the research that has been done in Palembang Hotel, it can be concluded that:1) The proportion of hotel access in Palembang City is $58.06 \%$ eligible. The proportion of access to the building environment is eligible at $58.06 \%$; the proportion of fire fighter access which is eligible is $100 \%$. The result of statistical analysis shows there is no relation between access to fire prevention system at hotel in Palembang city.2) The proportion of hotels in Palembang City which has a welibible water supply of $93.55 \%$. The result of statistical analysis shows there is no relation between water supply with fire prevention system in hotel in Palembang city. 3) The proportion of hotels in Palembang City which has a tools of rescue is $83.87 \%$. eligible. The proportion of hotels with eligible outlet facilities is $83.87 \%$; the proportion of hotels with emergency stair cases is $83.87 \%$ eligible; the proportion of hotels with exit road signs which is eligible is $70.97 \%$; the proportion of hotels with eligible fire assembly points is $80.65 \%$. The result of statistical analysis shows that there is correlation between tools or rescue and fire prevention system with $p$ value $=$ 0.026 and PR $10.50 \%$. 4) The proportion of hotels in Palembang City which has an active protection facility of $74.19 \%$. The proportion of hotels with alarms and detectors is $83.87 \%$; has pole hydrant is $67.74 \%$, has a $100 \%$ wall hydrant; automatic sprinkler $96.78 \%$; $90.33 \%$ 
has eligible fire extinguisher. The result of statistical analysis shows that there is no correlation between active protection system and fire prevention system. 5)The proportion of hotels in Palembang City which has a passive protection facility is $74.19 \%$. The proportion of hotels with $100 \%$ fire proof walls; has $70.96 \%$ fire proof door. The result of statistical analysis shows that there is relation between passive protection and fire prevention system with $\mathrm{p}=0.000$ and $\mathrm{PR}=0.33 \%$. 6) The knowledge of safety fire manager Hotel in Palembang city is $74.19 \%$ eligible. The result of analysis shows that there is a relation between passive protection and fire prevention system, with $\mathrm{p}=0.013$ and $\mathrm{PR}$ $=11.11 \%$.

According to the research result, here are some suggestion: 1) There needs to be regular repair and maintenance on active and passive protection facilities as well as life tools of rescue facilities that have been provided by the hotel. Regular inspection from the Fire Department at least once a year related to this need to be implemented. 2) There needs to be an increase in fire prevention knowledge not only to hotel staffs but as well as to management. Good knowledge if not supported by the availability of good infrastructure from management will not be nothing. Education and training and routine simulation must be implemented at least once a year. Every employee who just worked both daily freelance and permanent employees must be given induction / training education work safely and the introduction of work environment. 3) Any visitor of the hotel either stay or who use the services of the hotel in a short time (meetings, meetings, parties, etc.) is entitled to know the way out facilities provided by the hotel. Providing an evacuation trail map on the back of the door in each room would be more use full if the hotel officer explained directly to the visitors or the provision of evacuation line video information media via television available in every room. Not all visitors pay attention to the information posted behind the door of the room and not all visitors are able to read the information properly and correctly this is due to differences in the level of knowledge of each visitor. 4) The need for an integrated cross-sector licensing system between the ministry of tourism, the Public Works Department, the Fire Department, the City Planning Agency and the PHRI for hotel licensing to operate.5) A meeting between the ministry of tourism, the Public Works Department, PHRI and all hotel managers for the concept of fire prevention system at the hotel must be met according to the existing regulations. 6) The ministry of tourism is expected to conduct regular meetings and coaching with the hotel management, notification of any regulations that have just been published. 7) Occupational Safety and Health Education (SHE), one of the materials, fire prevention needs to be incorporated into the curriculum of the Tourism School, especially the hospitality department, since almost all workers in the hotel come from the school.8) It is hoped that there will be further research the safety of fire prevention system in hotels that influence the number of tourist visits.

It is hoped that there will be further research with more variables and research on the fire prevention system in hotels that influence the number of tourist visits.

\section{References}

1. Aktuell, Reiseanalyze, Informe de coyuntura del mercado turisticoalemăn, (Forschungs gemeinschaft und Reisen, 2003).

2. Campbell, R, Structure fires in hotels and motels, (National fire Protection Asosiastion Quincy, 2015).

3. Nasyaa Zainal., et al, A Description of the application of the fire management system in the former administrative city of jember, (Jember, Jember Univercity, 2013). 
4. Margarethe Kobes., et al, Way finding during fire evacuation; an analysis of unannounced fire drills in a hotel at night, (ElsevierSao Paulo, 2010).

5. International Labour Organization (ILO), Module five, (Training Manual for Occupational Safety and Health Managers and Workers, Jakarta, 2013).

6. The Ministry of General Occupation, The Ministry of general occupation rules, (Technical Requirements of Fire Protection System on Buildings and Environment, Jakarta, 2008).

7. The Ministry of General Occupation, The Ministry of general occupation decision, (Provision of Fire Prevention and Control on Buildings, Jakarta)

8. Rijanto, B, Fire and Building Planning (Mitra wacana media, Jakarta, 2010).

9. Sucipto, Cecep Dani, Safety and Occupational Health (Gosyen Publising, Jakarta, 2010)

10. $\mathrm{Hu}, \mathrm{Y}$, Research on the application of fault tree analysis for building fire (Elsevier, China, 2016)

11. The Ministry of General Occupation. The Ministry of general occupation rules. number 20 tahun 2009 about technical guidelines for urban fire protection management. (The Ministry of General Occupation, Jakarta, 2009) 